\title{
Incentives and inhibiting factors of eco-innovation in the Spanish firms.
}

\begin{abstract}
This paper investigates the incentives and inhibiting factors of eco-innovation capacities in the firm. Firms materialize the objectives of eco-innovation from a reactive attitude to external pressures, to a more proactive attitude that implies the voluntary incorporation of eco-innovation activities. This variability in the behaviour of companies with respect to the level of eco-innovation development has been a motivator for the research. However, despite the importance of this research question, this has been approached in a dispersed way from multiple approaches. From a dynamic capabilities perspective, we assume that the innovation capacity of the firm encourages eco-innovations. Our paper is focused on the process of ecoinnovation, identifying the elements that facilitate or hinder the eco-innovation in the firm. We study the Spanish case, using a panel from the Spanish Innovation Survey, with a sample of 5,461 Spanish firms. The results highlight that the complexity of the eco-innovation process negatively affects the decision to develop eco-innovations. However, our results suggest that institutions and organizations of the Spanish environment are making efforts to compensate these obstacles and provide incentives to develop eco-innovations.
\end{abstract}

Keywords: Eco-innovation; Innovation capacity; Spain; Incentives and inhibiting factors.

\section{Introduction}

Over lasts years, eco-innovation has been considered a driver of economic development (Constantini et al., 2017; Arena et al., 2017). This is the case, for example, of the use of biochar, aimed at revitalizing degraded soils, improving soil carbon sequestration, and increasing agronomic productivity (Spokas et al., 2012); the development of renewable energies as an alternative to fossil fuels (Ellabban et al., 2014); or the introduction of waste management, aimed at optimizing processes and their economic profitability (Maroušek, 2014). In this context, several studies highlight the relation between eco-innovation and firms, emphasizing the role of firms in the development of eco-innovation (Doran and Ryan, 2016; Liao, 2018a). Thus, the growth of demand for environmental improvement and the importance of sustainable development in the society has increased the number of techniques, products and services respectful with the environment. Vellinga and Herb (1999), and JovéLlopis and Segarra-Blasco (2018) conclude that in the context of industrial transformation, 
which implies changes in production and necessary patterns on the path to sustainable development, firms must play an active role.

Firms materialize the objectives of eco-innovation in the selection of activities and the degree to which they are developed (Doran and Ryan, 2016; Liao, 2018b). In this context, firms set objectives from a reactive attitude to external pressures, to a more proactive one that implies the voluntary incorporation of eco-innovation activities (Doran and Ryan, 2016; Jové-Llopis, and Segarra-Blasco, 2018). Thus, there is variability in the scope and depth of eco-innovation objectives. These include the compliance with legislation, such as for example the development of eco-innovations that aim at controlling waste (discharge and high toxicity emissions) and compliance with environmental standards; the implementation of environmental quality systems, for example the ISO 9001, 14001 and Integrated Management Systems (ISO, 2019); the creation of ecological products for new markets, including the application of Directive 2009/125/EC for the establishment of eco-design requirements for energy-related products (Bovea and Pérez-Belis, 2012); and finally, industrial symbiosis, in the context of circular economy (Lieder and Rashid, 2016; Baldassarre et al., 2019). This variability in the degree of firms' development of ecoinnovation has been a motivation for research to recognise the main drivers of environmental innovation in the company (Cuerva et al., 2014; Horbach et al., 2012). Most researchers have concentrated on the effect that policies and regulations have on the eco-innovation in the firm (Novellie et al., 2016; Liao, 2018a). Also, although in a dispersed manner, studies on ecoinnovation have also emerged from the field of industrial organization (Triguero et al., 2013; Peiró-Signes and Segarra-Oña, 2018), understanding the external drivers of environmental innovation (Bossle et al., 2016). More recently, the decision-making literature has advanced towards the understanding of internal factors to the company for the decision to develop ecoinnovation. Marousek (2013), in the study of the use of renewable energies in agriculture, points out how ethical, energy and financial factors affect the decision to adopt ecoinnovation objectives. Govindan et al. (2015) analyse the factors that affect the decision process of the evaluation and selection of green suppliers. Studying the development of biochar, Marousek et al. (2015) conclude that the decision to eco-innovate is a combination of social responsibility, risk, and experience. However, despite these efforts, few studies emphasize the innovation capabilities of the company as a driver in the development of ecoinnovation. Horbach et al. (2012) point out that it is necessary to continue investigating what factors motivate or hinder firms to develop eco-innovation to get a complete overview of the determinants of eco-innovation in the firm. 
Our study uses the dynamic capabilities theoretical approach to explore firms' ecoinnovation development. Following this approach, we assume that the innovation capacities of the firm encourage eco-innovations. Our work puts the emphasis on the process of ecoinnovation, identifying the elements that facilitate or hinder eco-innovation in the firm (Wicki and Hansen, 2017; Tang et al., 2018). Companies develop eco-innovation in a dynamic process of interaction of skills, abilities, routines and resources (Teece, 2007). We assume that this process is conditioned by the capacities that the firm has on that process, which is based on the factors that facilitate or hinder the development of innovation. Therefore, we consider that firms' decision to adopt eco-innovation objectives will be the result of the ease or difficulty in performing the process, as a consequence of the factors that facilitate or inhibit eco-innovation. Our research question is focused on identifying the factors that facilitate or hinder eco-innovation in the firm.

We test the research question using a panel data from the Spanish Innovation Survey (PITEC, 2013), with 5,461 Spanish firms. We study, firstly, how the management of the ecoinnovation process affects companies' decision to adopt eco-innovation. Thus, the uncertainties derived from the process, the market, and the management of the ecoinnovation, are the main factors to be analysed. Secondly, we study how different policies and actions in the firms' environment are affecting firms' eco-innovation objectives. Thus, we analyse facilitating elements such as the availability of the information sources, the existence of means to establish cooperation agreements, and the availability of public financing.

This research contributes to the eco-innovation literature with new empirical knowledge. We provide empirical evidence to understand what elements affect the proactivity of the firm in the development of environmental actions. Our work complements previous literature (Da Silva et al., 2017; Doran and Ryan, 2016) by highlighting that the control of the ecoinnovation process, affected by factors that facilitate or hinder environmental innovations, is another element to be considered in firms' eco-innovation objectives.

\section{Materials and Methods}

To explore our research question, the factors that facilitate or hinder eco-innovation capacities in the firm, we first present the conceptual framework and the model of our research, generating the hypotheses; second, we describe the research methodology, including data collection, measures and the econometric model.

\subsection{Conceptual Framework and Model}


Our paper is framed in the dynamic capabilities theory (Teece, 2007). Teece et al. (1997: 516) considered the dynamic capabilities as "the firm's ability to integrate, build, and reconfigure internal and external competencies to address rapidly changing environments". Thus, the dynamic capabilities are presented as specific and identifiable processes, considered the dynamic capabilities as foreseeable behavioural patterns, through which the organisation manages its resource, with the objective of obtaining the success of the company (Eisenhardt, \& Martin, 2000). Therefore, dynamic capabilities encompass the management of capabilities and resources of all functions of firms, with the final objective to develop innovations.

In our research, the model involves the eco-innovation developing processes and the impact on firms' decision (Figure 1). The model postulates that the eco-innovation entails the development of a dynamic process of capabilities, routines and resources that are influenced by the firms' degree of control, as consequence of the hindering or facilitating factors found in the process. Therefore, firms' decision to develop eco-innovation depends on the difficulty or perceived facilitate of performing this type of innovation.

Hindering Factors: the complexity of the eco-innovation process.

The innovation development process has been characterized as a complex process from the managerial point of view (De Medeiros et al., 2018; Arranz and Fernandez de Arroyabe, 2009). In this sense, the uncertainty of the process itself and the market, as well as the management of firms' resources and cooperation agreements for the eco-innovation, are a set of difficulties and obstacles that must be overcome in this process (Arranz and Fernandez de Arroyabe, 2006; Lundwall, 2007).

The first group of obstacles arises from the uncertainty of the process. Uncertainties of innovation outcomes, as well as the time invested in its realization, are sources of difficulties for firms to develop innovation (Tidd et al., 2005). The firm perceives that this uncertainty in the development of innovations could suppose a deviation in the budget, as a result of not achieving the technical solutions sought, therefore, more resources and/or more time than the expected need to be allocated. Lee and Park (2006) point out that this extra cost implies an added problem for the company. It is necessary to finance this extra cost and search for financing, which supposes an additional difficulty to the management of the innovation process, considering that the limited resources are allocated to the firm (Lee and Park, 2006; Lundwall, 2007). Therefore, the management of costs and financing of the development of eco-innovation will have a negative effect on firms' objectives to develop green innovation. 
The second group of obstacles arises from the complexity of managing the eco-innovation process. Arranz and Arroyabe (2009) point out that the innovation process involves the development of exploration and exploitation tasks in the firm. First, exploration requires experimenting and searching for activities to find new and emerging innovations capable of generating future sources of profits (Gilsing et al., 2008). Gilsing et al. (2008) point out that firms need to develop management systems for the acquisition of novel information on markets and technologies. Second, exploitation implies the extension and refinement of existing technologies, paradigms and competencies (Rothaermel and Deeds, 2004). In this case, the company must manage an adequate staff, with a level of competence appropriate to the needs of exploitation. The management of exploration and exploitation in the firm has been highlighted as difficult activities to combine. Thus, O'Reilly and Tushman (2004) noted that this involves managing different organizational and strategic requirements, generating tensions in the firm. These authors also argued that both orientations compete for the scarce resources of companies, which generates the need to manage the exchanges between the two in an adequate balance (O'Reilly and Tushman, 2004). Otherwise, the development of innovation is currently assumed in the literature to be a cooperative process with other organisations. However, Hagedoorn et al. (2006), and shows that the development of cooperation agreements implies several obstacles, for example, the necessary coordination of two or more partners, the discrepancies in the goals and cultural differences, and the problems derived of the relation among partners. In this sense, Hagedoorn et al. (2006) highlight that is important to search for suitable partners with the aim of mitigating the subsequent problems of the management of cooperation agreements. Therefore, as a consequence of the need to generate information, capabilities in the firm, and management of the search for partners, the management of the eco-innovation process, will have a negative impact on firms' objectives.

Finally, another group of obstacles that firms usually find in the development of innovations are those derived from the uncertainty of the market. Hagedoorn (2006) pointed out that uncertainty occurs in the face of ignorance of the consumer reaction to the innovative product. An example this is the ecological products in the agro-food sector, where the ecological product has an extra-cost compared to the similar non-ecological product (De Medeiros et al., 2018). In this case, the consumer will be willing to pay more if his perception of the relation quality-cost is acceptable. Although it is observed that there is an increase in the intangible value of the products (Sala et al., 2017; Mirata and Emtairah, 2005), the additional cost generates uncertainty in the firm, which implies the development of additional 
actions to achieve the acceptance of the product in the market (Rehfeld et al., 2007). This situation becomes more complicated if the market is dominated by established firms, which creates an added difficulty to the entry of new products/firms (Theyel, 2006). On the other hand, derived from the double effect of eco-innovation, the ecological advantages usually disappear as a consequence of the disincentive that exists to develop ecological research. Choi et al. (2016) point out that due to the fact that environmental knowledge has public good characteristics, it is relatively easy to copy the first innovators without assuming the research costs and risks. Therefore, the management of the eco-innovation process, as a consequence of the uncertainty of the market, will have a negative impact on firms' objectives.

\section{External facilitating factors in the eco-innovation objectives.}

By the mere fact of belonging to a geographical area, the companies are exposed to institutional elements that encourage the adoption and development of innovations. We assume, following Gilsing et al. (2008), that companies do not innovate alone: innovation is an interactive process of the different actors and institutions that participate in the innovation system. Thus, National Innovation Systems (NIS) have emerged as focal points for innovation and technology, as well as for facilitating the relationship and interaction between private companies, researchers and institutional actors (Lundvall, 2007; Wicki and Hansen, 2017). The interactions allow the sharing of risks and resources, reducing the times to develop innovations, and increasing the access to knowledge, and markets (Parida et al., 2014), which facilitate innovation development. To understand the dynamics of the innovation system, following Wicki and Hansen (2017, page 1121), we must identify the structural elements that have a positive influence on the process of innovation development. On the contrary, negative self-reinforcing dynamics can also appear when several factors are accumulated that prevent the system from favouring innovative dynamics (Wicki and Hansen, 2017). Therefore, the identification of these factors and their impact is a key element to promote an innovative system.

A first factor considered in the research of innovation is the readiness of information that the firm has in its environment. Carrion-Flores and Innes (2010) show that the information sources positively impact on the adoption of eco-innovation objectives. Amores-Salvado et al. (2015) highlight that information is a key element for the environmental management in firms. In this line, Rogers (2003: 172) considers that the decision to implement innovations is a process as "an information-seeking and information-processing activity". The firm becomes aware of the necessity of developing eco-innovation, evaluating the feasibility of this development (Rogers 2003). In this context, the environment in which the firm operates 
enables a continuous flow of information and knowledge exchange between actors on market, and eco-innovative possibilities (Wang et al., 2012). This information may come from the market, different institutions, trade fairs, seminars, and journals, among others (PITEC, 2013). Consequently, the eco-innovation decision might be affected, for example, by information about the existence of new regulations and certifications, new environmental technologies, or new market necessities. Therefore, information is an incentive for the firms, which will impact positively on the development of the eco-innovations.

A second factor is the establishment of collaboration agreements with other companies, organizations or institutions. Gilsing et al. (2008) point out that one of the ways of accessing the experience and knowledge acquired by other firms in their innovation activities is by establishing cooperation agreements with them. Thus, the development of cooperation agreements allows sharing the risks of innovative development (Hagedoorn et al., 2006). In this sense, and drawing parallelism with other types of innovation, it is that these cooperation agreements will positively influence the adoption of eco-innovations (Cuerva et al., 2014). For example, the cooperation with clients allows the development of new ecological products (Kemp et al., 2006). Additionally, the agreements of cooperation with suppliers permit the incorporation and development of innovations in energy saving or the reduction of waste and pollution (MIrata and Emtairah, 2005). In this line, De Marchi (2012) points out that the cooperation with suppliers enables eco-innovation, highlighting this effect as compared to other types of innovation. Finally, cooperation with universities has been considered a source of low-cost innovation (Koontz et al., 2015 Aragón-Correa). Therefore, cooperation agreements allow companies to generate a stock of shared knowledge, and risk sharing, having a favourable impact on firms' decision on eco-innovations development.

Finally, financial facilitators have been used to incentivize innovation in enterprises (Da Silva et al., 2017; Choi et al., 2016). As seen previously, the innovative development requires firms to have adequate financial resources to develop this process. In this context, the various institutions, whether local, national or international, develop financing facilities for innovations and eco-innovation, encouraging the incorporation of environmental objectives in the firm (Doran and Ryan, 2016; Horbach, 2008). Therefore, financial incentives in the process to develop eco-innovations will have a favourable impact on companies' objectives for eco-innovations development.

In Table 1b, we show the generated Hypotheses.

\subsection{Research Methodology}

2.2.1. Context: Spain and the development of eco-innovation 
The report of environmental innovation of the European Union points out that Spain appears in the 9th position in the Eco-Innovation Index performance ranking of the EU27 (Eco-Innovation Observatory, 2018). Following this report, the most important areas of ecoinnovation in Spain include 'eco-design, ecological engineering, energy efficiency, sustainable construction, urban greening systems, urban water systems and the efficiency of water' (Eco-Innovation Observatory, 2018, p. 53). However, Spain is below the European average in terms of the environmental products generated and the inputs for eco-innovation. The Eco-Innovation Observatory (2018) points out that the main weaknesses and barriers to ecological innovation in Spain are: the generation of organic products by companies, the deficiency of public support for developing eco-innovation and the emigration of qualified human capital.

\subsubsection{Data collection}

In this research, firm-level data is collected from the Spanish Technological Innovation Panel (PITEC). This database has been developed by the National Statistics Institute and replicates the questionnaire of the Community Innovation Survey, using a standardised questionnaire (OECD, 2009). This database has been widely used for innovation studies at the firm level, and more specifically for eco-innovation studies in Spain (for example, Cainelli et al., 2015). Likewise, the same questionnaire has been used as well in other European countries for eco-innovations studies (for example, Wagner, 2007).

PITEC is a database, which collects biannually all the innovation data of Spanish companies since 2001. PITEC contains firm-level data and it provides information about the company (employment, sales, geographic market, industry sector, etc.) as well as detailed information regarding its innovation activity (innovation expenditures, different kinds of innovation output, cooperation between firms, public financial support, barriers to innovation, and so on) $)^{1}$.

The population framework of PITEC is the Central Directory of Spanish Companies (DIRCE), which includes Spanish companies located in the national territory. PITEC has a sectoral coverage of agricultural, industrial, construction and service companies, following the NACE-2009 classification. From the geographical scope, the survey covers the whole of the national territory. The information collection method is a mixed system that includes

\footnotetext{
${ }^{1}$ More in detail, the PITEC questionnaire, containing 567 variables, is structured in the following sections: General data of the company; internal R\&D activities of the company; Purchase of R\&D services; Innovation activities carried out by the company; Innovation of products and processes; factors that hinder innovation activities in the company; intellectual and industrial property rights; Non-technological innovations The questions are measures with a combination of the scale, dummy, Likert and continuous.
} 
sending emails, interviews, with telephone support in the collection of the information, taking place in four months ${ }^{2}$.

The reference period for our study is 2010-2012. We proceeded to filter the sample, removing those firms for which the data of any of the years 2010-2012 was missing. In addition, we dropped micro-firms ( $<10$ employees), and firms involved in mergers and acquisitions. After a filtering process, our final sample is a balanced panel containing 5,461 firms, from which 3,462 firms have conducted some sort of eco-innovation over the period of study.

\subsubsection{Measures}

Measure of eco-innovations (see Table 2). The questionnaire from PITEC measures the environmental innovation with the following question: has the innovative activity carried out in your company oriented towards the following environmental objectives: i) Less energy per production; ii) Lower environmental impact; iii) Improvement in health and safety; and iv) Compliance with regulatory, environmental, health, or safety requirements. The environmental innovations are rated on a scale of 1 to 4 : a value of 1 is assigned if the degree of orientation is high; 2 if it is intermediate; 3 if it is low; and 4 if it is null.

Hindering factors in the innovation process (see Table 2). The PITEC questionnaire measures the importance of various hindering factors for innovation activities, classifying it into three types of obstacles.

- The first group of obstacles refers to the costs and financing of the companies of the innovation process, which is measured with three items: i) Lack of funds in the firm or group of firms; ii) Lack of funding from sources outside the company; iii) Innovation's high cost (Cronbach's Alpha: 0.778). The value of 0.778 of the Cronbach's Alpha, shows that the three variables are correlated ${ }^{3}$. Therefore, we create a new variable, Cost and Finance Obstacles, which brings together the three variables using Principal Component Analysis. The new variable explains $68.320 \%$ of the variance, with acceptable reliability as shown by the $\mathrm{KMO}=.624^{4}$ and significant $($ sig. $=0.000)$.

\footnotetext{
${ }^{2}$ PITEC sampling errors: Coefficient of variation of expenditure on innovation: $0.35 \%$. Coefficient of variation in the number of innovative companies: $1.38 \%$. Coefficient of variation in the number of innovative technology companies: $1.76 \%$. Coefficient of variation in the number of innovative non-technological companies: $1.57 \%$.

${ }^{3}$ Cronbach's alpha is a test used to estimate the reliability, or internal consistency, of a composite score, showing the level of correlation between more than two variables. In the literature, values higher than 0.600 are considered acceptable.

${ }^{4}$ The Kaiser-Meyer-Olkin (KMO) test takes values between 1, meaning that the new variable explains and perfectly adjust to the initial variables, and 0 , where the new variable the construct does not explain the model. In the literature values greater than 0.500 are allowed.
} 
- The second group of obstacles, in PITEC questionnaire, corresponds to the management of the innovation process. In this case, there are four items: i) Lack of information on technology; ii) Lack of information about the markets; iii) Lack of qualified personnel; iv) Difficulties in finding cooperation partners for innovation (Cronbach's Alpha: 0.752). The four variables are correlated and, therefore, we create a new variable (Innovation Process Obstacles) using Principal Components Analysis. The factor obtained explains $69.002 \%$ of the variance, with acceptable reliability as shown by its $\mathrm{KMO}=.675$ and sig. $=0.000$.

- Finally, the market obstacles that influence the development of the innovation is measured are measured with two items: i) Uncertainty regarding the demand for innovative goods and services; ii) Market dominated by established firms (Cronbach Alpha: 0.930). Also, we develop a new variable (Market Uncertainty), which explain the $81.559 \%$ of variance, and a reliability test $(\mathrm{KMO}=.811>0.500$, sig. $=0.000)$.

External facilitating factors in the innovation objectives (see Table 2). Regarding the external facilitating factors of the innovation process, we use the next variables from PITEC questionnaire.

- The first variable used is the Information Sources. The questionnaire considers both the intensity and the diversity of the sources of information consulted. The intensity of the use of sources is rated on a scale of 1 to 4 : a value of 1 is assigned if the degree of utilisation is high; 2 if it is intermediate; 3 if it is low; and 4 if it is null. The diversity of the sources distinguishes between ten different external sources: i) Suppliers; ii) Customers; iii) Competitors; iv) Consultants and commercial laboratories; v) Universities; vi) Public research bodies; vii) Technology centres; viii) Conferences, trade fairs and exhibitions; ix) Scientific journals; x) Professional and industry associations (Cronbach's Alpha: 0.979). The new variable explain the $87.014 \%$ of variance, with and reliability acceptable $(\mathrm{KMO}=$ .893 , sig. $=0.000)$.

- The second external factor is the Cooperation for Innovation, which is a dummy variable, being 1 if the company cooperate, and 0 if it does not.

- The third variable is the support of external Public Funding to the innovation processes, which has been measured with three items: i) From local or regional governments; ii) From the national government; iii) From the European Union.

\section{Control variables}

Testing the hypotheses required that we control for the possible effects of other variables to account for relevant effects that could influence the impact of the variables, and to provide new empirical evidence. The control variables used are: 
- Previous empirical studies have found firms' size to be an important element in the developing of new technological innovations (Damanpour and Schneider, 2006). Firm size is measured with the log of the number of staff in the firm (Firm Size).

- The second control variable measures whether firms belong to the manufacturing or services sector, is a dummy variable (Manufacturing/Services), being 0 if the company belongs to the manufacturing sector and 1 if it belongs to the service sector.

- A common variable in studies on innovation is the inclusion of a variable that records whether the firm is part of a group (Group), being 1 it the company belongs, and 0 if it does not.

- The final control variable is the international scope of the firm. PITEC questionnaire distinguishes four different geographical areas. We include a variable to control where the firm is operating: 0 if it is in the local or national market, 1 if is in the EU exclusively, and 2 if it operates in the US and other countries (International Market).

\subsubsection{Econometric model}

To test the first group of hypotheses that explore the impact of obstacles on the ecoinnovation objectives in the firm, we use an Ordinal Logit Regression Model (see Table 4b). Based on the questionnaire, we use four different specifications to analyse the effect of obstacles on eco-innovation. Models 1 to 4 have as dependent variables the four different types of eco-innovations (Less Energy; Lower Impact; Improvement Health and Safety; Regulatory Requirements). Moreover, Model 5 uses the encompassing variable Ecoinnovation as the dependent variable. This variable measures the degree of penetration of environmental objectives in the firm, and this is getting as the sum of the four ecoinnovations. As independent variables for the five models, we include obstacles factors (Cost and Finance; Innovation Process; Market Uncertainty), and four control variables.

Our econometric model is (Models 1 to 5, Table 4b):

$y=$ constant $+\beta_{1}($ Cost and Finance $)+\beta_{2}($ Innovation Process $)+\beta_{3}($ Market Uncertainty $)+$ $\beta_{4}($ size $)+\beta_{5}($ manufacturing $/$ services $)+\beta_{6}($ group $)+\beta_{7}($ International Market $)+e$

being:

y: depend variable (Less Energy; Lower Impact; Improvement Health and Safety;

Regulatory Requirements; Eco-innovations).

$\beta_{i}$ : Regression Coefficient.

$e$ : error terminus. 
Models 6 to 10 in Table $5 \mathrm{~b}$ explore the impact of facilitating factors on the eco-innovation objectives in the firm. Using Ordinal Logit Regression, Models 6 to 10 have as dependent variables the four different types of environmental objectives and, similarly Table 4b (Model 5), Model 10 has as dependent variable the environmental objectives. As explanatory variables, we include facilitating factors (Information Sources, Cooperation for Innovation, Public Funding: Local or Regional, National, and European Union) and four control variables.

The econometric model is (Models 6 to 10 , Table 5b):

$y=$ constant $+\beta_{1}($ Information Sources $)+\beta_{2}($ Cooperation for Innovation $)+\beta_{3}($ Local or Regional $)+\beta_{4}($ National $)+\beta_{5}($ European Union $)+\beta_{6}($ size $)+\beta_{7}($ manufacturing $/$ services $)+$ $\beta_{8}($ group $)+\beta_{9}($ International Market $)+e$

being:

y: depend variable (Less Energy; Lower Impact; Improvement Health and Safety;

Regulatory Requirements; Eco-innovations).

$\beta_{i}$ : Regression Coefficient.

$e$ : error terminus.

\section{Results and Discussion}

Table 3 shows the descriptive results of the variables analysed. We note that 3,462 firms, six out of ten of the sample (63.3\%), claim to have at least one eco-innovation objective. Our data highlights that the percentage of companies that develop eco-innovation in the manufacturing sector is greater $(70.1 \%)$ than in the service sector $(61.7 \%)$. Moreover, firms that declare a greater degree of internationalization in their activities assume eco-innovation objectives more frequently (67.7\%). In addition, $67.6 \%$ of the firms that belong to a group are carrying out eco-innovation activities. Regarding the impact of firms' size in the realization of eco-innovation, it is observed that between 60 and 70\% of SMEs and large firms assume eco-innovation objectives. Finally, it is noted that $100 \%$ of the firms that establish cooperation agreements to develop innovations declare to carry out at least one ecoinnovation activity. Likewise, firms that have developed at least one environmental innovation objective use external sources of information or have a R\&D department for innovations.

Table $4 \mathrm{~b}$ shows the factors that hinder the eco-innovation process in the firm. Regarding Hypothesis 1a, in Model 5, we observe that the costs and financing of the innovation process (Costs and Finance) have a negative and significant impact $(B=-0.554, \mathrm{p}<0.01)$ on the eco- 
innovation. These results corroborate our hypothesis, showing that lack of funds both internal and external to the firm, as well as the high cost of innovation, are obstacles in the development of eco-innovations. In reference to Hypothesis $1 \mathrm{~b}$, the results of Model 5 highlight that the management of the innovation process (Innovation Process) is a variable that has a negative impact $(\beta=-0.449, \mathrm{p}<0.01)$ on the adoption of eco-innovations, supporting the hypothesis that the difficulties of the process, such as the lack of information on technology and market, and the lack of qualified personnel, have a negative effect on the development of eco-innovations. Finally, Hypothesis 1c is supported, since the variable Market Uncertainty has a significant and negative impact $(\beta=-0.463, \mathrm{p}<0.01)$ on the development of eco-innovation, which indicates that the lack of market information and the uncertainty of the market have a negative effect on the development of eco-innovation in the firm. In general, regarding the hindering factors in the eco-innovation management, the results corroborate the literature showing that the cost and finance of eco-innovation are a disincentive for its development (Cuerva et al., 2014). These results are reinforced by the "double externality" hypothesis, which states that the costs of eco-innovation are a disincentive for the firm due to the social nature of environmental developments, which will subsequently allow other firms to access these eco-innovations without incurring the costs and risks (Amores-Salvado et al., 2015). Moreover, the results show the importance of market uncertainty for eco-innovation and that the potential viability of a product negatively affects the development of eco-innovation. This corroborates previous studies that noted that uncertainties in consumer perception and market saturation are an obstacle for eco-innovation (Cuerva et al., 2014). Furthermore, our results corroborate that management ambidexterity and the establishment of cooperation agreements for eco-innovative development are additional difficulties in this process.

Table $5 \mathrm{~b}$ shows the effect of the external facilitating factors in the eco-innovation of the firm. In Model 10, we observe that the variable Cooperation for Innovation $(\beta=0.123, \mathrm{p}<$ $0.05)$ and Information Sources $(\beta=0.246, \mathrm{p}<0.01)$ have a positive effect on the ecoinnovations. These results support the hypotheses $2 \mathrm{a}$ and $2 \mathrm{~b}$, pointing out that the establishment of cooperation agreements and the use of information sources for innovative development have a positive effect on the development of eco-innovation in the firm. Furthermore, the Public Funding variable has also a positive effect on the development of eco-innovation (Model 10$)$, both locally $(\beta=0.223, \mathrm{p}<0.05)$ and nationally $(\beta=0.329, \mathrm{p}$ $<0.01)$. However, EU funding is not significant in developing eco-innovations, in spite of the fact that these policies have been mainly aimed at financing projects for new environmental 
technologies (especially in SMEs), as well as encouraging the creation of European business and technology centres (Mazzani and Zoboli, 2006). Therefore, our results show that the regional or national levels have a positive effect on the eco-innovations in companies. Therefore, concerning external facilitating factors in the eco-innovations, our results confirm previous studies that highlight the necessity to obtain scientific information from universities and research centres, international standards from environmental agencies, and information regarding the readiness of production inputs from suppliers in the developing of ecoinnovations (Kemp et al., 2006). Moreover, the results highlight the key role of cooperation in the environmental innovation objectives. Previous literature has shown vertical and horizontal cooperation is very important, reducing the environmental impact and ensuring the eco-friendly features of inputs. Availability of information and reciprocal learning (from cooperation) between clients and suppliers have shown to be key in reaching environmental goals, in combination with the collaboration with universities and research institutions, in light of the complexity of developing eco-innovations (Cuerva et al., 2014; Cai and Zhou, 2014). Additionally, in line with Horbach (2008), and Manzini and Zoboli (2006) our results show that financial incentives facilitate the eco-innovation development, especially at a local, regional and national geographical level.

Finally, in relation to the control variables, our results show a positive impact on the size of firms on eco-innovation. Although our results show that small and medium companies have assumed at least one environmental objective, our analysis reinforces the hypothesis about the size, showing that this is a key element in the development of eco-innovation in the company. This has been a classic result in the innovation and environmental literature, showing that large companies have a greater predisposition for the adoption of environmental objectives. In fact, the SMEs, with limited financial resources, cannot implement lengthy processes in the development of competencies, as well as supporting important ecological activities (De Medieros et al., 2018; Marin et al., 2015). Moreover, the results show that the manufacturing sector is more sensitive to the eco-innovation objectives than the service sector. This confirms that the manufacturing sector has a greater incidence of environmental problems, such as the long-established issue of the elimination of toxic waste (both gaseous and liquid), as well as the challenge of energy saving. Finally, the results illustrate that the support of the company group has a positive impact on certain types of innovation objectives. It is well established in the literature that the corporate environmental strategy determines the adoption of environmental quality standards, management, and clean production processes. This evidence shows that the group determines environmental policies, which is a component 
of the corporate social responsibility policy of the firms (Choi et al., 2016; Horbach et al., 2012).

\section{Conclusions}

The goal of our work is to investigate the incentives and inhibiting factors of ecoinnovation in the firm, using a sample of Spanish firms. Unlike other studies that have been focused on the effect of policies and regulations (Choi et al., 2016, Constantini et al., 2017), are framed in the field of industrial organization ((Triguero et al., 2013; Bossle et al. al., 2016), or take a decision-making perspective (Marousek et al., 2015), our paper differs by considering that the innovation capacity of the firm is a key factor in the development of ecoinnovation. Our results show that the innovation capacities of the firm encourage environmental innovations. Thus, companies develop eco-innovation in a dynamic process of interaction of skills, abilities, routines and resources for innovation. Moreover, the results highlight that this process is conditioned by factors that hinder or facilitate the eco-innovation capacity of the firms. More in detail, the first group of hypotheses highlight that the perception of the high costs and the necessary financing that development of eco-innovation suppose hindering factors in the development of the eco-innovation. The lack of knowledge, the qualified personnel and the information is the second group of obstacles in the development of eco-innovations. Finally, the uncertainty of the demand for eco-innovative goods and services and the saturation of the market, appear as obstacles for the development of eco-innovation in the firm. On the other hand, we have proposed a group of hypotheses that suggest that the efforts of the National Innovation Systems can compensate for these obstacles, incentivising the development of eco-innovations. Our results corroborate these hypotheses pointing out that an adequate framework that provides information to companies both for the search of partners and market possibilities, as well as the existence of financial incentives facilitate eco-innovation in the firm.

From our results, we can propose some management actions for the firms and policymakers. Firstly, we have seen that an obstacle for companies is the lack of market information. It would be necessary to develop push and pull policies that involve companies. On the one hand, companies must take advantage of the fact that consumer positively value intangible aspects of products and services, developing a new market for the eco-innovation. The European Union (2015) points out that this market is fast-growing far above the average (from $17 \%$ in 1975 to $84 \%$ in 2015). On the other hand, companies should assume ecoinnovation as a strategic objective, seeking not only to reduce costs or gain efficiency, but 
also to gain competitive advantages through the positioning of products, services, and brands (Sala et al., 2017). In this sense, Boston Consulting Group (2009) showed that consumers perceive the products with better environmental performance with higher quality, and consequently, their willingness to pay more is higher (Manget et al., 2009). Second, our results highlight the deficiencies of external financing as a difficult for firms to develop ecoinnovation activities. In this sense, specific programs should be developed for firms, encouraging and financing the eco-innovations. In addition, the permeability of environmental actions and development should be increased in the rest of the R\&D and innovation policies. Third, the lack of knowledge of the company to develop environmental innovation requires a series of measures. Companies should investigate new eco-innovative developments. In this sense, vertical cooperation is very important both with customers and with suppliers for the creation of new products and services. The cooperation with clients might provide complementary skills or knowledge, mitigating the risks and difficulty associated with the implementation of the eco-innovation (Hagedoorn et al., 2000). In addition, cooperation with suppliers is necessary for the eco-innovation. In this sense, ecoinnovation translates into an increase in environmental requirements over suppliers, exerting traction on the entire supply chain. The companies that are leading this process transfer their environmental requirements through the implementation of environmental systems (ISO 14001) in the supply chain. Lastly, these findings indicate two suggestions that can be made to policy-makers. Thus, it is necessary to increase the permeability of eco-innovation in $R \& D$ and innovation programs. The proximity of the two types of innovation should facilitate ecoinnovative development. Our results show that there exists parallelism between the knowledge and competencies necessary for the development of eco-innovation and those needed for conventional innovation, highlighting the interrelationship of both processes, so that firms that have already developed innovations are more susceptible to develop ecoinnovations.

Finally, like any research, our paper is subject to the limitations of the sample choice. The more important limitation is the geographical scope; our empirical study is limited to Spain. Obviously, the question is open about the generalisation of the results. Research must aim to study the eco-innovation developing in countries, with more institutional and financial support to develop eco-innovation in the firm.

\section{References}


Amores-Salvadó, J., Martin-de Castro, G., Navas-López, J. E. 2015. The importance of the complementarity between environmental management systems and environmental innovation capabilities: A firm level approach to environmental and business performance benefits. Technological Forecasting and Social Change, 96, 288-297.

Arranz, N., Fernandez de Arroyabe, J.C. 2006. Joint R\&D projects: Experiences in the context of European technology policy. Technological Forecasting and Social Change, 73(7), 860-885.

Arranz, N., Fernandez de Arroyabe, J.C. 2009. Complex joint R\&D projects: From empirical evidence to managerial implications. Complexity, 15(1), 61-70.

Baldassarre, B., Schepers, M., Bocken, N., Cuppen, E., Korevaar, G., Calabretta, G. 2019. Industrial Symbiosis: towards a design process for eco-industrial clusters by integrating Circular Economy and Industrial Ecology perspectives. Journal of Cleaner Production. https://doi.org/10.1016/j.jclepro.2019.01.091

Bovea, M., Pérez-Belis, V. 2012. A taxonomy of ecodesign tools for integrating environmental requirements into the product design process. Journal of Cleaner Production, 20(1), 61-71.

Bossle, M. B., de Barcellos, M. D., Vieira, L. M., Sauvée, L. 2016. The drivers for adoption of eco-innovation. Journal of Cleaner Production, 113, 861-872.

Cai, W.G., Zhou, X.L. 2014. On the drivers of eco-innovation: empirical evidence from China. Journal of Cleaner Production, 79, 239-248.

Cainelli, G., De Marchi, V., Grandinetti, R. 2015. Does the development of environmental innovation require different resources? Evidence from Spanish manufacturing firms. Journal of Cleaner Production, 94, 211-220.

Carrión-Flores, C. E., Innes, R. 2010. Environmental innovation and environmental performance. Journal of Environmental Economics and Management, 59(1), 27-42.

Choi, Y., Bone, Ch., Zhang, N. 2016. Sustainable policies and strategies in Asia: Challenges for green growth. Technological Forecasting and Social Change, 112, 134-137

Costantini, V., Crespi, F., Palma, A. 2017. Characterizing the policy mix and its impact on eco-innovation: A patent analysis of energy-efficient technologies. Research Policy, 46(4), 799-819.

Cuerva, M.C., Triguero-Cano, Á., Córcoles, D. 2014. Drivers of green and non-green innovation: empirical evidence in low-tech SMEs. Journal of Cleaner Production, 68, 104-113. 
Da Silva, R.F., Batistella, M., Moran, E.F. 2017. Socioeconomic changes and environmental policies as dimensions of regional land transitions in the Atlantic Forest, Brazil. Environmental Science \& Policy, 74, 14-22.

De Marchi, V. 2012. Environmental innovation and R\&D cooperation: Empirical evidence from Spanish manufacturing firms. Research Policy, 41(3), 614-623.

De Medeiros, J. F., Lago, N. C., Colling, C., Ribeiro, J. L. D., Marcon, A. 2018. Proposal of a novel reference system for the green product development process (GPDP). Journal of Cleaner Production, 187, 984-995.

Del Río, P., Peñasco, C., Romero-Jordán, D. 2015. Distinctive features of environmental innovators: an econometric analysis. Business Strategy and the Environment, 24(6), 361385 .

Demirel, P., Kesidou, E. 2011. Stimulating different types of eco-innovation in the UK: Government policies and firm motivations. Ecological Economics, 70(8), 1546-1557.

Doran, J., Ryan, G. 2016. The importance of the diverse drivers and types of environmental innovation for firm performance. Business Strategy and the Environment 25(2), 102-119.

Eco-Innovation Observatory 2018. Eco-innovation Index. Eco-innovation Observatory. European Commission. http://www.eco-innovation.eu/index.php/eco-innovation-index.

Eisenhardt, K. M., Martin, J. A. 2000. Dynamic capabilities: what are they? Strategic Management Journal, 21(10-11), 1105-1121.

Ellabban, O., Abu-Rub, H., Blaabjerg, F. 2014. Renewable energy resources: Current status, future prospects and their enabling technology. Renewable and Sustainable Energy Reviews, 39, 748-764.

Gilsing, V., Nooteboom, B., Vanhaverbeke, W., Duysters, G., van den Oord, A. 2008. Network embeddedness and the exploration of novel technologies: Technological distance, betweenness centrality and density. Research Policy, 37(10), 1717-1731.

Govindan, K., Rajendran, S., Sarkis, J., Murugesan, P. 2015. Multi criteria decision making approaches for green supplier evaluation and selection: a literature review. Journal of Cleaner Production, 98, 66-83.

Hagedoorn, J. 2006. Understanding the cross-level embeddedness of interfirm partnership formation. Academy of Management Review, 31(3), 670-680.

Horbach, J., Rammer, C., Rennings, K. 2012. Determinants of eco-innovations by type of environmental impact. The role of regulatory push/pull, technology push and market pull. Ecological Economics, 78, 112-122. 
ISO, 2019. Integrated Management Systems. International Organization for Standardization. https://www.iso.org/news/2013/02/Ref1709.html.

Jové-Llopis, E., Segarra-Blasco, A. 2018. Eco-innovation strategies: A panel data analysis of Spanish manufacturing firms. Business Strategy and the Environment, 27(8), 1209-1220

Kemp, R, Arundel, A., Parto, S. 2006. 21 Indicators for environmental innovation: what and how to measure. Eds: Marinova, D., Annandale, D., \& Phillimore, J. The International Handbook on Environmental Technology Management. Edgar Elgar Publishing.

Kiefer, C. P., Carrillo-Hermosilla, J., Del Rio, P., Barroso, F. J. C. 2017. Diversity of ecoinnovations: A quantitative approach. Journal of Cleaner Production, 166, 1494-1506.

Koontz, T. M., Gupta, D., Mudliar, P., Ranjan, P. 2015. Adaptive institutions in socialecological systems governance: A synthesis framework. Environmental Science \& Policy, $53,139-151$.

Lee, J. D., Park, C. 2006. Research and development linkages in a national innovation system: Factors affecting success and failure in Korea. Technovation, 26(9), 1045-1054.

Liao, Z. 2018a. Institutional pressure, knowledge acquisition and a firm's environmental innovation. Business Strategy and the Environment. https://doi.org/10.1002/bse.2036.

Liao, Z. 2018b. Environmental policy instruments, environmental innovation and the reputation of enterprises. Journal of Cleaner Production, 171, 1111-1117.

Liao, Z., Xu, C. K., Cheng, H., Dong, J. 2018. What drives environmental innovation? A content analysis of listed companies in China. Journal of Cleaner Production, 198, 15671573 .

Lieder, M., Rashid, A. 2016. Towards circular economy implementation: a comprehensive review in context of manufacturing industry. Journal of Cleaner Production, 115, 36-51.

Lundvall, B. A. 2007. National innovation systems-analytical concept and development tool. Industry and Innovation, 14(1), 95-119.

Manget, J., Roche, C., Münnich, F., 2009. Capturing the green advantage for consumer companies. The Boston Consulting Group, vol. 13.

Maroušek, J., 2013. Study on agriculture decision-makers behavior on sustainable energy utilization. Journal of Agricultural and Environmental Ethics, 26(3), 679-689.

Maroušek, J., 2014. Novel technique to enhance the disintegration effect of the pressure waves on oilseeds. Industrial Crops and Products, 53, 1-5.

Maroušek, J., Hašková, S., Zeman, R., Vaníčková, R. 2015. Managerial preferences in relation to financial indicators regarding the mitigation of global change. Science and Engineering Ethics, 21(1), 203-207. 
Marin, G., Marzucchi, A., Zoboli, R. 2015. SMEs and barriers to Eco-innovation in the EU: exploring different firm profiles. Journal of Evolutionary Economics, 25(3), 671-705.

Mazzanti, M., Zoboli, R. 2006. Economic instruments and induced innovation: the European policies on end-of-life vehicles. Ecological Economics, 58, 318-337.

Mirata, M., Emtairah, T. 2005. Industrial symbiosis networks and the contribution to environmental innovation: the case of the Landskrona industrial symbiosis programme. Journal of Cleaner Production, 13(10), 993-1002.

Novellie, P., Biggs, H., Roux, D. 2016. National laws and policies can enable or confound adaptive governance: Examples from South African national parks. Environmental Science \& Policy, 66, 40-46.

OECD 2009. Sustainable manufacturing and eco-innovation. Framework, practices and measurement. Synthesis report. Paris. Available at: www.oecd.org/sti/innovation/sustainablemanufacturing.

O'Reilly, C. A., Tushman, M. L. 2004. The ambidextrous organization. Harvard Business Review, 82(4), 74.

Parida, V., Oghazi, P., Ericson, A. 2014. Realization of open innovation: A case study in the manufacturing industry. Journal of Promotion Management, 20(3), 372-389.

Peiró-Signes, Á., Segarra-Oña, M. 2018. How past decisions affect future behavior on ecoinnovation: An empirical study. Business Strategy and the Environment, 27(8), 12331244.

PITEC 2013. Panel de Innovacion Tecnologica. Fundacion Española para la Ciencia y Tecnologia. https://icono.fecyt.es/PITEC/Paginas/descarga_bbdd.aspx.

Porter, M. E., Van der Linde, C. 1995. Toward a new conception of the environmentcompetitiveness relationship. Journal of Economic Perspectives, 9(4), 97-118.

Rehfeld, K.M., Rennings, K., Ziegler, A. 2007. Integrated product policy and environmental product innovations: an empirical analysis. Ecological Economics, 61, 91-100.

Rogers, E.M. 2003. Diffusion of innovations. Fifth edition. New York: Free Press.

Rothaermel, F., Deeds, D. 2004. Exploration and Exploitation Alliances in Biotechnology: A System of New Product Development. Strategic Management Journal, 25, 201-221.

Sala, S., McLaren, S. J., Notarnicola, B., Saouter, E., Sonesson, U. 2017. In quest of reducing the environmental impacts of food production and consumption. Journal of Cleaner Production, 140, 387-398.

Spokas, K. A., Cantrell, K. B., Novak, J. M., Archer, D. W., Ippolito, J. A., Collins, H. P., Boateng, A., Lima, I. M., Lamb, M.C. McAloon, J. M., Lentz, R. D. 2012. Biochar: a 
synthesis of its agronomic impact beyond carbon sequestration. Journal of Environmental Quality, 41(4), 973-989.

Tang, M., Walsh, G., Lerner, D., Fitza, M. A., Li, Q. 2018. Green Innovation, Managerial Concern and Firm Performance: An Empirical Study. Business Strategy and the Environment, 27(1), 39-51.

Teece, D. J. 2007. Explicating dynamic capabilities: the nature and microfoundations of (sustainable) enterprise performance. Strategic Management Journal, 28(13), 1319-1350.

Teece, D. J., Pisano, G., Shuen, A. 1997. Dynamic capabilities and strategic management. Strategic management journal, 18(7), 509-533.

Tidd, J., Bessant, J., Pavitt, K. 2005. Managing innovation integrating technological, market and organizational change. John Wiley and Sons Ltd.

Triguero, A., Mondéjar, M.L., Davia, M.A. 2013. Drivers of different types of eco-innovation in European SMEs. Ecological Economics, 92, 25-33.

Vellinga, P., Herb, N. 1999. Industrial Transformation Science Plan. IHDP Report No. 12.

Wagner, M. 2007. On the relationship between environmental management, environmental innovation and patenting: Evidence from German manufacturing firms. Research Policy, 36(10), 1587-1602.

Walz, R., Kuhlmann, S. 2005. Nachhaltigkeitsinnovationen in systemischer Perspektive. In Erde 2.0-Technologische Innovationen als Chance für eine Nachhaltige Entwicklung? (pp. 278-310). Springer, Berlin, Heidelberg.

Wang, Y., Vanhaverbeke, W., Roijakkers, N. 2012. Exploring the impact of open innovation on national systems of innovation-a theoretical analysis. Technological Forecasting and Social Change, 79(3), 419-428.

Wicki, S., Hansen, E. G. 2017. Clean energy storage technology in the making: An innovation systems perspective on flywheel energy storage. Journal of Cleaner Production, 162, 1118-1134. 
Table 1a

Conceptualisation of eco-innovation

Eco-innovation - Eco-innovation aims to develop new processes, products and techniques to avoid environmental damage (Kemp et al., 2006).

- Eco-innovation also includes new knowledge and organizational innovation (OECD, 2009).

- Eco-innovation is the innovation for sustainability (Vellinga and Herb, 1999); Walz and Kuhlmann, 2005)

Key elements of - Eco-innovation has to do with innovations that generate environmental eco-innovation ${ }^{5}$ improvements.

- Eco-innovation must obtain an additional value for the producer and the consumer.

- Eco-innovation must reach the market either by opening new business niches or by generating better competitive behaviour.

- Eco-innovation must imply a net environmental improvement.

\section{Eco-innovation and Innovation}

\begin{tabular}{ll}
\hline Similarities & Eco-innovation as an innovation that is able of producing environmental and \\
& sustainable products and services. (Kemp et al., 2006) \\
\hline Differences & Eco-innovation generates a 'win-win' setup characterized by compatibility of \\
& economic development and a sustainable economy (Arena et al., 2017). \\
- Eco-innovation is aimed at fostering sustainable development (Walz and Kuhlmann, \\
\\
- Eco5; Wellinga and Herb, 1999). \\
- solutions (Choi et al., 2016). \\
Eco-innovation has as characteristic the double externality. Double externality refers \\
to the absence of incentives for firms to invest in eco-innovation. The reduction of \\
environmental damage by innovators reduces the pressure on other polluting firms, \\
since there is a social benefit, without the latter having to adopt any measures (Porter \\
and Van der Linde, 1995). \\
- Eco-innovation has as characteristic the regulatory push/pull effect. While new \\
technology solves environmental problems in the firms, environmental regulation and \\
policy are responsible, also, for these environmental improvements. (Constantini et \\
al., 2017; Choi et al., 2016).
\end{tabular}

${ }^{5}$ Eco-innovation is often used interchangeably with environmental innovation. However, environmental innovation is linked with environmental technology or eco-efficiency, which pursues the development of more sustainable production and consumption models, with less environmental impact and with an efficient and responsible use of the natural resources (Jové-Llopis and Segarra-Blasco, 2018; Liao, 2018b; Liao et al., 2018; Kiefer et al., 2017). 


\section{Figure 1}

Conceptual Model

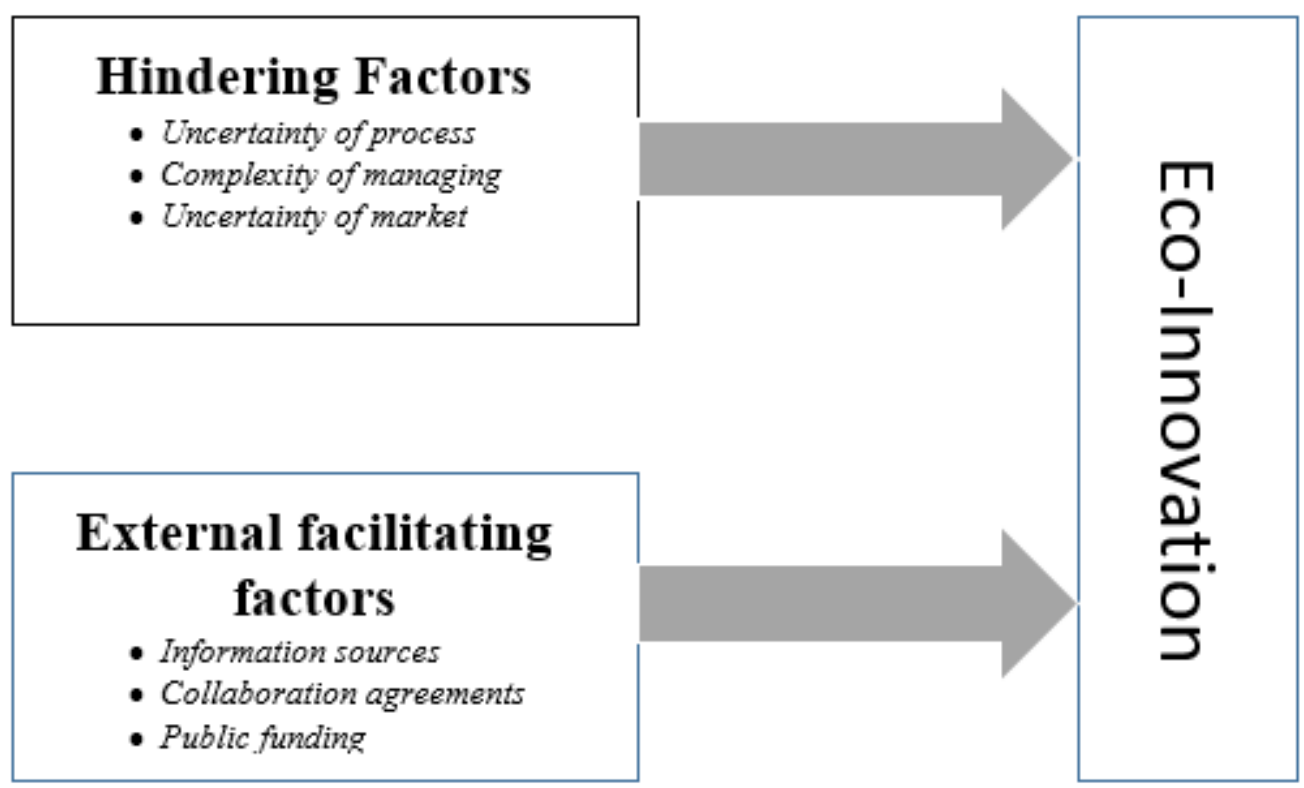

\section{Table 1b}

Hypotheses

\section{Hindering Factors: the complexity of the eco-innovation process}

Hypothesis la: The obstacles derived from the management of costs and financing of the eco-innovation process have a negative effect on firms' eco-innovation.

Hypothesis $1 \mathrm{~b}$ : The difficulties in managing the eco-innovation process have a negative effect on firms' eco-innovations.

Hypothesis 1c: The uncertainty of the market has a negative effect on firms' eco-innovations.

\section{External facilitating factors in the eco-innovation objectives}

Hypothesis $2 a$ : The available information has a positive effect on firms' eco-innovations.

Hypothesis $2 b$ : The cooperation agreements have a positive effect on firms' eco-innovations.

Hypothesis 2c: Financial facilities have a positive effect on firms' eco-innovations.

Table 2

Variables and Measures

\begin{tabular}{|c|c|c|}
\hline Measure & Variables & Scale \\
\hline Eco-innovation & $\begin{array}{l}\text { - Less energy per production; } \\
\text { - Lower environmental impact; } \\
\text { - Improvement in health and safety; } \\
\text { - Compliance with regulatory, environmental, health, or safety } \\
\text { requirements }\end{array}$ & 1,0 \\
\hline \multicolumn{3}{|c|}{ Hindering factors in the eco-innovation process } \\
\hline Costs and & Lack of funds in the firm or group of firms; & $1,2,3,4$ \\
\hline
\end{tabular}




\begin{tabular}{|c|c|c|}
\hline Finance & $\begin{array}{l}\text { - Lack of funding from sources outside the company; } \\
\text { - Innovation's high cost }\end{array}$ & \\
\hline $\begin{array}{l}\text { Innovation } \\
\text { Process }\end{array}$ & $\begin{array}{l}\text { - Lack of information on technology; } \\
\text { - Lack of information about the markets; } \\
\text { - Lack of qualified personnel; } \\
\text { - } \text { Difficulties in finding cooperation partners for innovation }\end{array}$ & $1,2,3,4$ \\
\hline $\begin{array}{l}\text { Market } \\
\text { Uncertainty }\end{array}$ & $\begin{array}{l}\text { - Uncertainty regarding the demand for eco-innovative goods and } \\
\text { services; } \\
\text { - Market dominated by established firms }\end{array}$ & $1,2,3,4$ \\
\hline \multicolumn{3}{|c|}{ External facilitating factors in the eco-innovation objectives } \\
\hline Information Sources & $\begin{array}{l}\text { - Suppliers; } \\
\text { - Customers; } \\
\text { - Competitors; } \\
\text { - Consultants and commercial laboratories; } \\
\text { - Universities; } \\
\text { - Public research bodies; } \\
\text { - Technology centres; } \\
\text { - Conferences, trade fairs and exhibitions; } \\
\text { - Scientific journals; } \\
\text { - Professional and industry associations } \\
\end{array}$ & 1,0 \\
\hline $\begin{array}{ll}\text { Cooperation } & \text { for } \\
\text { Innovation } & \\
\end{array}$ & - Cooperation & 1,0 \\
\hline $\begin{array}{l}\text { Public } \\
\text { Funding }\end{array}$ & $\begin{array}{l}\text { - From local or regional governments; } \\
\text { - From the national government; } \\
\text { - From the European Union. }\end{array}$ & 1,0 \\
\hline \multicolumn{3}{|c|}{$\begin{array}{l}\text { Variables of control } \\
\end{array}$} \\
\hline Size & - Logarithm of the number of staff in the firm & Continuous \\
\hline Sector & - Manufacturing/Services & 1,0 \\
\hline Group & - Group & 1,0 \\
\hline International & $\begin{array}{l}\text { - Local; } \\
\text { - National; } \\
\text { - EU; } \\
\text { - Other countries (China and India) }\end{array}$ & 1,0 \\
\hline
\end{tabular}

\section{Table 3}

Exploratory Analysis

\begin{tabular}{llllll}
\hline Variables & \multicolumn{5}{c}{ Eco-innovation } \\
& & $\mathbf{0}$ & \multicolumn{1}{c}{$\mathbf{1}$} & Total \\
& $\mathbf{N}$ & $\mathbf{\%}$ & $\mathbf{N}$ & $\mathbf{\%}$ & $\mathbf{N}$ \\
\hline Environmental & 1999 & 36.7 & 3462 & 63.3 & 5461 \\
Manufacturing & 893 & 29.9 & 2117 & 70.1 & 3010 \\
Services & 937 & 38.3 & 1514 & 61.7 & 2451 \\
Internationalization & 1366 & 23.3 & 3700 & 67.7 & 5461 \\
Cooperation & 0 & 0 & 2353 & 100 & 2353 \\
Size: & & & & & \\
10-49 & 973 & 38.9 & 1528 & 61.1 & 2501 \\
50-249 & 565 & 30.0 & 1318 & 70.0 & 1883 \\
>250 & 398 & 36.9 & 679 & 63.1 & 1077 \\
Group & 1274 & 32.4 & 2657 & 67.6 & 3931 \\
R\&D Department & 0 & 0 & 3663 & 100 & 3663 \\
Information Sources & 0 & 0 & 5461 & 100 & 5461 \\
Public Funding & 16 & 7.8 & 2022 & 92.2 & 2038 \\
\hline
\end{tabular}




\section{Table 4a}

Correlation Analysis

\begin{tabular}{|c|c|c|c|c|c|c|c|c|}
\hline & & 1 & 2 & 3 & 4 & 5 & 6 & 7 \\
\hline 1 . & Costs and Finance & 1 & & & & & & \\
\hline 2 . & Innovation Process & .000 & 1 & & & & & \\
\hline 3. & Market Uncertainty & .000 & .000 & 1 & & & & \\
\hline 4. & Firm Size & $-.034^{* *}$ & -.002 & $-.022^{*}$ & 1 & & & \\
\hline 5 . & Manufacturing/Services & $-.036^{* *}$ & $-.056^{* *}$ & $-.064^{* *}$ & $.101^{* * *}$ & 1 & & \\
\hline 6. & Group & $-.116^{* *}$ & -.016 & .014 & $.141^{* *}$ & .003 & 1 & \\
\hline 7. & International & .008 & $.035^{* *}$ & $.112^{* * *}$ & $-.032^{* *}$ & $-.379^{* *}$ & $.139^{* *}$ & 1 \\
\hline
\end{tabular}


Table 4b

Regression Analysis between hindering factors and eco-innovations

\begin{tabular}{|c|c|c|c|c|c|c|c|c|c|c|}
\hline & \multirow{2}{*}{\multicolumn{2}{|c|}{$\begin{array}{c}\text { Model 1 } \\
\text { Less Energy }\end{array}$}} & \multicolumn{2}{|c|}{ Model 2} & \multicolumn{2}{|c|}{ Model 3} & \multicolumn{2}{|c|}{ Model 4} & \multicolumn{2}{|c|}{ Model 5} \\
\hline & & & Lower & mpact & $\begin{array}{r}\text { Improvem } \\
\text { and } S\end{array}$ & $\begin{array}{l}\text { nt Health } \\
\text { fety }\end{array}$ & $\begin{array}{r}\text { Regul } \\
\text { Requir }\end{array}$ & $\begin{array}{l}\text { tory } \\
\text { ments }\end{array}$ & $\begin{array}{r}\text { Enviror } \\
\text { Obje }\end{array}$ & $\begin{array}{l}\text { mental } \\
\text { ives }\end{array}$ \\
\hline & Estimated & Error & Estimated & Error & Estimated & Error & Estimated & Error & Estimated & Error \\
\hline Costs and Finance & $-.560 * * *$ & .025 & $-.552 * * *$ & .025 & $-.529 * * *$ & .025 & $-.540 * * *$ & .025 & $-.554 * * *$ & .024 \\
\hline Innovation Process & $-.441 * * *$ & .023 & $-.418 * * *$ & .023 & $-.434 * * *$ & .023 & $-.427 * * *$ & .023 & $-.449 * * *$ & .023 \\
\hline Market Uncertainty & $-.434 * * *$ & .021 & $-.440 * * *$ & .022 & $-.447 * * *$ & .022 & $-.472 * * *$ & .022 & $-.463 * * *$ & .021 \\
\hline Firm Size & $\begin{array}{l}6.016 \mathrm{E}- \\
005^{* * *}\end{array}$ & $\begin{array}{l}1.317 \mathrm{E}- \\
005\end{array}$ & $\begin{array}{l}6.947 \mathrm{E}- \\
005 * * *\end{array}$ & $\begin{array}{l}1.378 \mathrm{E}- \\
005\end{array}$ & $\begin{array}{l}6.706 \mathrm{E}- \\
005 * * *\end{array}$ & $\begin{array}{l}1.364 \mathrm{E}- \\
005\end{array}$ & $\begin{array}{l}5.459 \mathrm{E}- \\
005 * * *\end{array}$ & $\begin{array}{l}1.346 \mathrm{E}- \\
005\end{array}$ & $\begin{array}{l}6.369 \mathrm{E}- \\
005 * * *\end{array}$ & $\begin{array}{l}1.281 \mathrm{E}- \\
005\end{array}$ \\
\hline Manufacturing/Services & $-.338 * * *$ & .043 & $-.292 * * *$ & .043 & $-.316 * * *$ & .043 & $-.293 * * *$ & .043 & $-.353 * * *$ & .043 \\
\hline Group & $.606 * * *$ & .041 & $.569 * * *$ & .041 & $.547 * * *$ & .041 & $.530 * * *$ & .041 & $.585 * * *$ & .041 \\
\hline International & $.517 * * *$ & .024 & $.525^{* * * *}$ & .024 & $.525^{* * *}$ & .024 & $.527 * * *$ & .024 & $.520 * * *$ & .024 \\
\hline -2 Log Likelihood & 25005.845 & & 25014.919 & & 24916.472 & & 24928.322 & & 36569.727 & \\
\hline Chi-Square & 1980.649 & & 1992.468 & & 1992.222 & & 1955.286 & & 2089.918 & \\
\hline$d f$ & 7 & & 7 & & 7 & & 7 & & 7 & \\
\hline Sig. & .000 & & .000 & & .000 & & .000 & & .000 & \\
\hline Cox and Snell & .194 & & .195 & & .195 & & .192 & & .204 & \\
\hline McFadden & .073 & & .073 & & .074 & & .072 & & .054 & \\
\hline
\end{tabular}


Table 5a

Correlation analysis

\begin{tabular}{|c|c|c|c|c|c|c|c|c|c|c|}
\hline & & 1 & 2 & 3 & 4 & 5 & 6 & 7 & 8 & 9 \\
\hline 1 . & Information Sources & 1 & & & & & & & & \\
\hline 2. & Cooperation & $.382^{* *}$ & 1 & & & & & & & \\
\hline 3. & Local or Regional & $.357^{* *}$ & $.225^{* *}$ & 1 & & & & & & \\
\hline 4. & National & $.444^{* *}$ & $.315^{* *}$ & $.311^{* *}$ & 1 & & & & & \\
\hline 5. & European Union & $.274^{* *}$ & $.251^{* *}$ & $.292^{* *}$ & $.329^{* *}$ & 1 & & & & \\
\hline 6. & Firm Size & $.057^{* *}$ & $.071^{* * *}$ & .008 & .019 & $.036^{* *}$ & 1 & & & \\
\hline 7. & Manufacturing/Services & $-.130^{* *}$ & $.030^{*}$ & -.011 & $-.033^{* *}$ & $.066^{* *}$ & $.101^{* *}$ & 1 & & \\
\hline 8. & Group & $.157^{* *}$ & $.183^{* *}$ & $.034^{* *}$ & $.102^{* *}$ & .019 & $.141^{* *}$ & .003 & 1 & \\
\hline 9. & International & $.325^{* *}$ & $.067^{* *}$ & $.117^{* * *}$ & $.200^{* *}$ & $.087^{* * *}$ & $-.032^{* *}$ & $-.379^{* *}$ & $.139^{* *}$ & 1 \\
\hline
\end{tabular}


Table 5b

Regression Analysis between facilitating factors and eco-innovations

\begin{tabular}{|c|c|c|c|c|c|c|c|c|c|c|}
\hline \multirow{3}{*}{ Variables } & \multicolumn{2}{|c|}{ Model 6} & \multicolumn{2}{|c|}{ Model 7} & \multirow{2}{*}{\multicolumn{2}{|c|}{$\begin{array}{c}\text { Model 8 } \\
\begin{array}{c}\text { Improvement Health } \\
\text { and Safety }\end{array}\end{array}$}} & \multirow{2}{*}{\multicolumn{2}{|c|}{$\begin{array}{c}\text { Model 9 } \\
\text { Regulatory } \\
\text { Requirements }\end{array}$}} & \multirow{2}{*}{\multicolumn{2}{|c|}{$\begin{array}{c}\text { Model 10 } \\
\text { Environmental } \\
\text { Objectives }\end{array}$}} \\
\hline & \multicolumn{2}{|c|}{ Less Energy } & \multicolumn{2}{|c|}{ Lower Impact } & & & & & & \\
\hline & Estimated & Error & Estimated & Error & Estimated & Error & Estimated & Error & Estimated & Error \\
\hline Information Sources & $.234 * * *$ & .004 & $.243 * * *$ & .004 & $.247 * * *$ & .004 & $.248 * * *$ & .004 & $.246 * * *$ & .004 \\
\hline Cooperation for Innovation & $.097 *$ & .056 & $.143 *$ & .058 & $.107 *$ & .058 & $.091 * *$ & .054 & $.123 * *$ & .052 \\
\hline Public Funding: & & & & & & & & & & \\
\hline - Local or Regional & $.141 *$ & .071 & $.254 * *$ & .073 & $.242 * *$ & .073 & $.234 * *$ & .074 & $.223 * *$ & .067 \\
\hline - National & $.302 * *$ & .067 & $.304 * * *$ & .068 & $.352 * * *$ & .068 & $.390 * *$ & .069 & $.329 * * *$ & .063 \\
\hline - European Union & .129 & .105 & .129 & .108 & .003 & .107 & -.017 & .109 & -.020 & .098 \\
\hline Firm Size & $3.773 \mathrm{E}-005^{* *}$ & $\begin{array}{l}1.423 \mathrm{E}- \\
005\end{array}$ & $\begin{array}{l}5.446 \mathrm{E}- \\
005 * * *\end{array}$ & $\begin{array}{l}1.494 \mathrm{E}- \\
005\end{array}$ & $\begin{array}{l}5.158 \mathrm{E}- \\
005^{* *}\end{array}$ & $\begin{array}{l}1.491 \mathrm{E}- \\
005\end{array}$ & $\begin{array}{l}2.768 \mathrm{E}- \\
005^{*}\end{array}$ & $\begin{array}{l}1.485 \mathrm{E}- \\
005\end{array}$ & $\begin{array}{l}4.329 \mathrm{E}- \\
005^{* *}\end{array}$ & $\begin{array}{l}1.323 \mathrm{E}- \\
005\end{array}$ \\
\hline Manufacturing/Services & $-.758 * * *$ & .054 & $-.752 * * *$ & .055 & $-.751 * * *$ & .055 & $-.732 * * *$ & .055 & $-.853 * * *$ & .052 \\
\hline Group & $.215^{* * *}$ & .052 & $.160 * *$ & .053 & $.120 *$ & .053 & .081 & .053 & $.126 * *$ & .050 \\
\hline International & .003 & .031 & -.008 & .031 & .008 & .031 & .011 & .031 & -.013 & .029 \\
\hline -2 Log Likelihood & 15553.828 & & 15178.983 & & 15001.842 & & 15008.376 & & 26196.655 & \\
\hline Chi-Square & 11534.478 & & 11932.412 & & 12013.633 & & 11978.430 & & 12557.869 & \\
\hline$d f$ & 9 & & 9 & & 9 & & 9 & & 9 & \\
\hline Sig. & .000 & & .000 & & .000 & & .000 & & .000 & \\
\hline Cox and Snell & .716 & & .728 & & .730 & & .729 & & .746 & \\
\hline Nagelkerke & .755 & & .768 & & .771 & & .770 & & .757 & \\
\hline McFadden & .425 & & .440 & & .444 & & .443 & & .324 & \\
\hline
\end{tabular}

